\title{
28 Research Square \\ Ethno Botanical Studies of District Dera Ghazi Khan, Province Punjab, Pakistan
}

\author{
Tahira Aziz Mughal \\ Lahore College for Women University \\ Hamna Yasin \\ Lahore college for women university Lahore Pakistan \\ Zubaida Yousaf ( $\sim$ z4zubaida@yahoo.com ) \\ Lahore College for Women University \\ Ismat Naeem Naeem \\ Lahore College for Women University Lahore
}

\section{Research}

Keywords: Ethno botanical, Solanaceae, Medicinal plant, Herbs, Traditional knowledge

Posted Date: August 28th, 2020

DOI: https://doi.org/10.21203/rs.3.rs-60138/v1

License: (9) This work is licensed under a Creative Commons Attribution 4.0 International License. Read Full License 


\section{Abstract \\ Background}

The chief aim of this study was to enlist the Ethnobotanical uses of plants in Dera Ghazi Khan, Punjab, Pakistan. Due to unique geographical and climatic conditions, Pakistan has a great floral diversity. Plants have been used by the indigenous people for treatment of different ailments since long. They are still dependent on the plants for their domestic purposes. Moreover, plants are used as first aid to treat diverse ailments such as hepatic disorders, cardiac diseases, neurological diseases, anticancer, respiratory diseases, ENT problems, gynecological problems etc. The traditional uses of medicinal plants lead to the discovery of natural drugs. This is first quantitative ethno medicinal documentation of medicinal plants in Dera Ghazi Khan. Punjab, Pakistan.

\section{Methods}

This ethno botanical information was collected from about 200 informants including male and female. Sample size was determined by statistical formula. The informative data was based on semi-structured interviews, group discussions, Questionnaire and field visits. Then the data was analyzed by applying different quantitative indices such as Informant Consent Factor (ICF), Use value (UV), Relative Frequency of Citation (RFC) and the Fidelity level (FL).

\section{Results}

Almost 185 plants belonging to 52 families were reported. Most-frequently cited families were Astreaceae (20 species) and Solanaceae (10 species). The most dominant life form was herbs (51\%). The most-used plant parts were leaves (68\%), followed by whole plant (65\%), Most common mode of administration is extraction (50\%). Generally herbal medicines were acquired from fresh plant material. Many species were reported with their different medicinal uses as has been reported in literature.

\section{Conclusions}

This ethno botanical documentation revealed that the plants are still used by natives of rural areas in their day-to-day lives. This study provides basis for the conservation of local flora. Plants with high ICF, UV and FL can be further used for phytochemical and pharmacological studies. This documentation could provide baseline information which can be used to develop new plant-based commercial drugs.

\section{Introduction}

Various botanical uses of plants represents a long history of human interactions with the environment. Plants used for traditional medicine contain a wide range of substances that can be used to treat chronic 
as well as infectious diseases. A vast knowledge of how to use the plants against different illnesses may be expected to have accumulated in areas where the use of plants is still of great importance. [1]. The medicinal value of plants lies in some chemical substances that produce a definite physiological action on the human body. The most important of these bioactive compounds of plants are alkaloids, flavonoids, tannins and phenolic compounds. [2]

Rural communities, in particular Paliyar tribes, depend on plant resources mainly for herbal medicines, food, forage, construction of dwellings, making household implements, sleeping mats, and for fire and shade. The use of medicinal plants as traditional medicines is well known in rural areas of many developing countries. [3]

Pakistan is rich in plant resources, particularly the medicinal plants. [4] More than 6,000 species of higher plants and 4,000 spices of fungi has been recognized and established in the Peshawar region. At least 1,000 medicinal plants species were reported from Pakistan [5] of which 500 species were commonly used in health care practices and 350 were traded for billions of Rupees to the national and international markets. Most of the medicinal plants available in the market or supplied directly to the pharmaceutical industries are extracted from the rural forest. [6]

Traditional healers claim that their medicine is cheaper and more effective than modern medicine. In developing countries, low-income people such as farmers, people of small isolate villages and native communities use folk medicine for the treatment of common infections. [7]

Medicinal plants have provided a source of inspiration for novel drug compound as plant derived medicine has made significant contribution to world human health. [8]. The important necessity and patentability of medicinal plants in practice of medicine today is well established and cannot be over looked. The use of alternative medical therapy increased the interest of pharmacologists and herbalists over the past decade. Plant medicine had become a topic of global importance. A lot of interest has been taken in investigation of medicinal source. A large number of these medicinal plants are used in the form of powder, decoction and infusion for treatment of various diseases including the infection caused by microbes with per amount of success by Hakims and local people. [9]

Dera Ghazi Khan is quite rich tropical regions of Punjab. Ethno medicinal study of this area has never been conducted. The climate of the area is quite hot. The main languages spoken in the District include Urdu and Punjabi. There is a lack of satisfactory health-care facilities, thus resulting in high maternal mortality rate (MMR) and infant mortality rate (IMR). Almost all ethnic groups use herbal medicines to cure different diseases, and these groups are rich with indigenous knowledge regarding the use of medicinal plants. Plants are used for food, shelter and therapeutic agents. However, lack of precise knowledge about the use able parts, proper time of collection and wasteful methods of collection lead to mishandling of these plants. So, the indigenous knowledge is going to be useless. Few studies have been carried out previously on Dera Ghazi Khan but no work has been done on quantitative approaches of medicinal plants in District Dera Ghazi Khan. Hence ethno medicinal survey is planned for Dera Ghazi 
Khan Punjab to document the traditional uses of medicinal plants in the area before the information is lost.

\section{Objective:}

The main objective of present study was

- To document the indigenous therapeutic knowledge of plants.

- compile profile of medicinal plants by using quantitative indices

- Evaluation of available ethno botanical data.

\section{Study Area:}

Dera Ghazi Khan District occupies area of 9,359 square miles. Its position in respect of area both in Pakistan and West Pakistan is $9^{\text {th }}$. ( Fig: 1). The district is named after the headquarters town Dera Ghazi Khan, which was founded 500 years ago by Ghazi Khan Mirrani, who was a great cattle-owner and was attracted by the abundant supply of grass.

This district is in the extreme south-western district of Multan division. It lies between north latitudes $28^{\circ}$ $20^{\prime}$ and $31^{\circ} / 5^{\prime}$ and east longitudes $69^{\circ} 35^{\prime}$ and $70^{\circ} 59^{\prime}$. It has a unique location and it is bounded on the north by Dera Ismail Khan district, on the east by a fixed boundary with the Alipur tehsil of Muzafargarh district, running roughly parallel with the Tndus upto the Panjnad confluence and further south by a fixed boundary with the Rahim Yar Khan in district, on the south lies the district of Jacobabad while on the west foothills of Suleiman Range. [10]

\section{Material And Methods}

The study was conducted and several visits were made on seasonal basis to Dera Ghazi Khan. The study was based on direct communication with the local inhabitants and local Hakims of the area. This information was then compared with available literature and found to be authentic. Material and other necessary information was collected from the council offices, Forestry, Wild life and Fisheries Department of the concerned area.

Table no: 1 Names and Addresses of Some Hakims and Local Persons who filled the Questionnaire 


\begin{tabular}{|c|c|c|}
\hline Sr. & \multirow{2}{*}{$\begin{array}{l}\text { Name of Hakim/ } \\
\text { Local People }\end{array}$} & \multirow[t]{2}{*}{ Address } \\
\hline \# & & \\
\hline 1 & Hakim Shuja Ahmed Tahir & Block No 15 Dera Ghazi Khan \\
\hline \multicolumn{3}{|l|}{2} \\
\hline 2 & Hakim Abdual Rehman & Jampur Road ,D.G.Khan \\
\hline 3 & Hakim Ibraheem Laghari & Block No 15 Dera Ghazi Khan \\
\hline 4 & Hakim Atta Muhammad & Block No 04 Dera Ghazi Khan \\
\hline 5 & Hakim Siraj Ahmed & Block No 04 Dera Ghazi Khan \\
\hline 6 & Hakim Musa Bansaar & Block No 12 Dera Ghazi Khan \\
\hline 7 & Prof.Mumtaz & Jampur Road, D.G.khan \\
\hline 8 & Mrs.Sahib Jan & Block No 16 Dera Ghazi Khan \\
\hline \multicolumn{3}{|l|}{9} \\
\hline 9 & Mrs.Karim Baloch & Saki Sarwer Road Dera Ghazi Khan \\
\hline 10 & Mr.Abdul Rahim & Gidder wali ,D.G.Khan \\
\hline 11 & Mr.Abdul Rehman & Gidder wali ,D.G.Khan \\
\hline 12 & MrsZanib Qadir Buksh & Sarwar Wali Road ,Chanab ,Muzzafar Ghar \\
\hline 13 & Mr.Sarwer Baloch & Raki Monh, Sakih Sarwer. \\
\hline 14 & Mr.Sabbir Sadoozi & Raki Monh, Sakih Sarwer. \\
\hline 15 & Mrs.Ameer Mahi & Jampur Road Choti. \\
\hline
\end{tabular}

Inventory The data obtained is checked and compared with the existing literature. Hence the indigenous knowledge about the plant resources, medicinal uses, religious and cultural aspect such as population density was also documented

\section{Quantitative Analyses of Ethno botanical data}

The documented ethno botanical data will be elucidated to define plant parts, and preparation methods. Various quantitative indices will be used i.e.

1. Use Value (UV),

2. Relative Frequency of Citation (RFC),

3. the Informant Consensus factor (ICF), and

4. the Fidelity Level (FL) 


\section{Use Value (UV)}

The UV of reported species was calculated using the following formula. [11]

$\mathrm{UV}=\mathrm{U} / \mathrm{n}$

Where UV is the use value of species, " $U$ " is the total number of use reports per species, and " $n$ " represents the total number of informants interrogated for a given plant. UVs are higher if there are many use reports of a plant, implying that the plant is important, whereas they are near zero.

\section{Relative Frequency Citation (RFC)}

The RFC was calculated using the following formula [12]

$\mathrm{RFC}=\mathrm{FC} / \mathrm{N}(0<\mathrm{RFC}<1)$ :

This relation displays the local prominence of every species, and it is calculated by dividing the FC, the number of informants reporting the use of the species divided by the total number of informers contributing in the survey $(\mathrm{N})$

\section{Informant Consensus Factor (ICF)}

ICF is calculated by the following formula [13]

$\mathrm{ICF}=\left(\mathrm{N}_{\mathrm{ur}}-\mathrm{N}_{\mathrm{t}}\right) /\left(\mathrm{N}_{\mathrm{ur}}-1\right)$

Where " $\mathrm{Nur}_{\mathrm{ur}}$ " mentions the number of use reports for a particular ailment category and "Nt" refers to the number of taxa used for a particular ailment category. The result of this consensus ranges from zero to 1 . A high value (close to 1) specifies that taxa are used by the large proportion of the informants for a number of conditions related to that broad category, whereas the low value (close to 0 ) indicates that the plants are chosen randomly for a few or a single condition or that informants did not exchange information about the use of plants. [14]

\section{Fidelity Level (FL)}

FL points out the preference shown for one species over others, for treating a particular ailment. [15] The high FL confirms high usage of the plant species for a particular ailment, whereas low FL confirms a wide range of medicinal uses but with a low frequency for each ailment. It was calculated by the following formula:

$F L=I_{p} / I_{u} \times 100 ;$

Where " $I_{p}$ " is the number of informants stating the use of a species for a particular ailment category. Whereas " $\mathrm{I}_{\mathrm{u}}$ " is the number of informants stating the use of that plant for any ailment category. 


\section{Results And Discussion}

\section{Demographic data}

Five field trips (to cover seasonal variations) were carried out to gather ethno medicinal data of medicinal plants. The total duration of the field study from June 2019 to March 2020. A total of 200 informants were interviewed. Among the 200 informants, mostly were indigenous people (Table 2). A large number of people were in the age of $70-80$ years (35\%). Due to the lack of some educational facilities in that area, most of the informants have completed their 10 years education (69.5\%). Most of the informants spoke Punjabi and very frequently spoke Urdu. The majority of informants were male $(60 \%)$ rather than female $(40 \%)$.

\section{Table no 2: Demographic study of informants in Dera Ghazi Khan}




\begin{tabular}{|c|c|c|c|c|}
\hline Sr. No. & Variation & Category & No of Person & $\%$ age \\
\hline \multirow[t]{2}{*}{1} & Informant Category & Local Inhabitants & 194 & $97 \%$ \\
\hline & & Local Hakims & 6 & $3 \%$ \\
\hline \multirow[t]{2}{*}{2} & Gender & Male & 120 & $60 \%$ \\
\hline & & Female & 80 & $40 \%$ \\
\hline \multirow[t]{8}{*}{3} & Age & Less than 20 & 0 & $0 \%$ \\
\hline & & $20-30$ & 20 & $10 \%$ \\
\hline & & $30-40$ & 05 & $2.5 \%$ \\
\hline & & $40-50$ & 10 & $5 \%$ \\
\hline & & $50-60$ & 25 & $12.5 \%$ \\
\hline & & $60-70$ & 40 & $20 \%$ \\
\hline & & $70-80$ & 70 & $35 \%$ \\
\hline & & More then 80 & 30 & $15 \%$ \\
\hline \multirow[t]{8}{*}{4} & Educational Background & Illiterate & 10 & $5 \%$ \\
\hline & & Completed 5 years education & 05 & $2.5 \%$ \\
\hline & & Completed 8 years education & 20 & $10 \%$ \\
\hline & & Completed 10 years education & 139 & $69.5 \%$ \\
\hline & & Completed 12 years education & 10 & $5 \%$ \\
\hline & & Some under Grade Degree & 15 & $7.5 \%$ \\
\hline & & Graduate & 0 & $0 \%$ \\
\hline & & Master & 01 & $0.5 \%$ \\
\hline
\end{tabular}

\section{Medicinal plant diversity}

Dera Ghazi Khan due to its topographic diversity is abundant in plants especially medicinal plants used by the local population for herbal tea, applications and decoctions. No study on Ethno medicinal plants was ever carried out in this region hence it was selected for this study and plants were categorized on the basis of information provided by the local population and Hakims practicing ethno-medicine.

Results of ethno medicinal studies were based on 189 plant species belonging to 52 families collected from different areas of DG Khan (Fig no: 2). Among them were 3 families of Monocots while the remaining 49 families represented the Dicots. The families well represented were Asteraceae (20), Acanthaceae (03), Cactaceae (03), Papilionaceae (09), Lamiaceae (05), Poaceae (04) Rosaceae (04), Amaranthaceae (06), Solanaceae (11), Apiaceae (06), Euphorbiaceae (05), Chenopodiaceae(08), 
Asclepiadaceae (07), Malvaceae (03), Zygophyllaceae (04), Portulaceae (02), Polygonaceae (04), Mimosaceae (11), Nyctaginaceae (02), Geraniaceae (02), Boraginaceae (06), Salvadoraceae (02), Caesalpiniaceae (09), Convolvulaceae (02), Liliaceae (06), Meliaceae (02), Tamaricaceae (02), Moraceae (04), Myrtaceae (02), Apocynaceae (03), Capparidaceae (04), Cactaceae (02), Palmaceae (03), Tamaricaceae (02), Brassicaceae, Rubiaceae, Sapindaceae, Violaceae, Zingiberaceae, Pedaliaceae, Lauraceae, Rhamnaceae, Resedaceae, Fumariaceae, Oxalidaceae, Ficoidaceae, Sapindaceae, Aizoaceae, Bignoniaceae, Cannabinaceae, Oleaceae, Frankeniaceae, Verbenaceae, Berberidaceae and Cucurbitaceae by one species each. For each species botanical name, family, local name, part used, method of preparation, dose administration and ailments treated are mentioned in the description.

\section{Life forms}

In this survey, herbs were documented with highest frequency (51\%), then herbaceous shrubs (29\%) which were followed by trees (13\%), and weeds (7\%) (Fig no. 3). Dominancy of herbs in making herbal remedies is due to its ubiquitous growth and easy collections of herbs as compared to trees and shrubs. Besides this, herbs can be manipulated with easiness in herbal preparation methods and extraction of bioactive compounds. [16]

\section{Parts of medicinal plants used for curing diseases:}

According to the survey, Leaves were mostly used by the people of DG Khan for curing diseases as $69.5 \%$ as shown in the Fig below. Leaves are mostly used because they are easily collected. After leave, Whole plant $(67 \%)$ is used for the preparation of herbal medicines for curing diseases by the people. Then whole plant is followed by root (40\%) because they require less effort and are frequently used for curing diseases. (Fig no 4). Least used parts are Buds, sap, tuber, petals, pod, Rhizome etc. They are used 0.5 to $1 \%$ as ailments.

\section{Form and mode of utilization}

In this survey, mostly plants were reported for internal applications. They were used either in the form of decoction (50\%) or in the form of Infusion (25\%) (Fig no: 5). This form of utilization is common in other parts of Pakistan particularly and in World generally. The decoction was made by boiling the plant parts in water $[17,18]$. While $20 \%$ were recommended for external use in the form of paste. The majorities of herbal medicines were prepared from fresh plant material rather than dried material.

\section{Quantitative analyses of ethno botanical data}

\section{Informant Consensus Factor (ICF)}

ICF was determined for 18 ailments (Hepatic disorders, Gynecological disorders, Renal disorders, ENT problems, General infection, Vernal diseases, Dermatological diseases, Neurological disorders, Respiratory diseases, GIT problems, Sexual diseases, Hair related problems, Cardiac disorder, Wound healing, Urinary disorders, Muscle disorders, Animal diseases and Antidote). The value of ICF for these 18 
ailments was ranging from 0.05 to 0.88 (Table 2). Commonly the value of ICF for disease treatment depends upon the availability of plant species in that area [19]. The highest value of ICF was reported for ENT problems (0.88), urinary disorders (0.57) and respiratory diseases (0.35). It showed that ENT problems were the most common disease in the study area and most of the people had knowledge about its cure. They were using 19 different species (Martynia annua, Bauhinia veriegata, Prosopis spicigera, Helianthus annuus, Artemisia scoparia, Rhazya stricta, Calligonum polygonoides, Lycium barbarum, Eclipta alba, Capsicum annuum, Azadirachta indica, Eucalyptus globulus, Boerhavia procumbens, Prosopis cineraria, Acacia Senegal, Abutilon indicum, Indigofera oblongifolia, Conyza Canadensis and Calotropis procera). These nineteen species were not only used for ENT problems in this region but also reported from other regions of Pakistan. While the lowest value of ICF was for Sexual and hair related problems that may be due to lack of communication among the informants in the study area [19].

\section{Table no. 3 ICF value of plants used for the treatment of various diseases}




\begin{tabular}{|c|c|c|c|c|c|}
\hline Category of diseases & $\begin{array}{l}\text { No. of use } \\
\text { reports }\end{array}$ & $\begin{array}{l}\% \text { Age of use } \\
\text { reports }\end{array}$ & $\begin{array}{l}\text { No. of taxa } \\
\text { used }\end{array}$ & $\begin{array}{l}\% \text { Age of } \\
\text { taxa }\end{array}$ & ICF \\
\hline Hepatic disorders & 31 & 5.83 & 21 & 4.88 & 0.5 \\
\hline $\begin{array}{l}\text { Gynecological } \\
\text { disorders }\end{array}$ & 25 & 4.7 & 18 & 4.16 & 0.17 \\
\hline Renal disorders & 27 & 5.08 & 24 & 5.58 & 0.13 \\
\hline ENT problems & 35 & 6.59 & 19 & 4.41 & 0.88 \\
\hline General infection & 101 & 19.02 & 86 & 20 & 0.17 \\
\hline Vernal diseases & 21 & 3.95 & 20 & 4.65 & 0.05 \\
\hline $\begin{array}{l}\text { Dermatological } \\
\text { diseases }\end{array}$ & 115 & 20.9 & 106 & 24.65 & 0.08 \\
\hline $\begin{array}{l}\text { Neurological } \\
\text { disorders }\end{array}$ & 4 & 0.75 & 3 & 0.69 & 0.5 \\
\hline Respiratory diseases & 97 & 18.26 & 72 & 16.74 & 0.35 \\
\hline GIT problems & 3 & 0.56 & 2 & 0.46 & 0.5 \\
\hline Sexual diseases & 2 & 0.37 & 1 & 0.23 & 0 \\
\hline $\begin{array}{l}\text { Hair related } \\
\text { problems }\end{array}$ & 2 & 0.37 & 1 & 0.23 & 0 \\
\hline Cardiac disorder & 17 & 3.2 & 16 & 3.72 & 0.06 \\
\hline Wound healing & 10 & 1.88 & 8 & 1.86 & 0.28 \\
\hline Urinary disorders & 12 & 2.25 & 8 & 1.86 & 0.57 \\
\hline Muscle disorders & 29 & 5.46 & 25 & 5.81 & 0.16 \\
\hline Animal diseases & 31 & 5.83 & 21 & 4.88 & 0.5 \\
\hline Antidote & 25 & 4.7 & 18 & 4.16 & 0.17 \\
\hline
\end{tabular}

\section{Uses Value (UV)}

In this study, UV ranged from 0.4 to 0.90 (Table 3). The highest UV was recorded for Fagonia indica (0.90), Daucus carota (0.89), Foeniculum vulgare, Tamarix diocica, Albizzia lebbek and Capsicum annuum (0.89 each). Plants with high UV were also used in many parts of Pakistan. As they are used to develop the herbal drug after pharmacological and phytochemical screening in the future. [20] The lowest UV was reported for Prosopis cineraria and Phoenix sylvestris (0.4 each). Most of the informants were not familiar about these plant species and had little knowledge about their ethno medicinal uses. Lower UV values indicated less knowledge about particular species in the study area. 


\section{Table: 4 Ethno botanical uses of plants in Dera Ghazi Khan, Pakistan (Separate file Attached)}

\section{Relative Frequency of Citation (RFC)}

The value of RFC ranged from 0.1 to 0.95 . (Table no: 3 ). The highest value of RFC present in Melia azedarach and Carissa opaca ( 0.95 each). It can be seen that plants with highest RFC are the most common plant in that region and majority people agreed by its medicinal value [21]. While the lowest value of RFC was present in Capparis decidua and Melilotus alba (0.1 each)

\section{Fidelity Level (FL)}

In present study the FL ranged from 18 to $82 \%$ (Table 4). The higher the FL value the more would be use of plant. The highest value of FL was present in Daucus carota (82\%). These plants were used by informants for disease cure and other purposes. The choice of informants dealing with the specific ailments indicated maximum value of FL [19], while lowest FL value was in Foeniculum capillacerm (18.18\%).

The study was aimed to carry out to record the plants growing in the Dera Ghazi Khan and to report ethno medicinal uses about the species of plant growing in district Dera Ghazi Khan. They were used to cure different type of diseases like hepatic disorders, Skin infections, cardiac Diseases, Urinary diseases, Antidote, fever, cough, ENT problems etc. People use these plants either in the form of decoction, powder, infusion or paste. Some of the plants are used along with the combination with milk or some specialized foods and various plant species have been found to cure such illness across different ethnic communities [22]. An immense knowledge of how to use the plants against different diseases may be expected to have accumulated in areas where the use of plants is still of great importance [1].

Present study is compared with the Study conducted in 2014 in Bahawalpur. It was observed that they recorded 123 species out of which 34 species were not similar to the study area while all other species are similar to the study area. When uses are compared to the area then it is concluded that $24.19 \%$ uses are common in both areas while $75.80 \%$ plants with dissimilar uses were reported. Aerva javanica was reported to be used as Sore throat, guinea-worm, malaria, eyewash, diarrhea, and help in childbirth and snakebite while in study area in Dera Ghazi Khan it is used for Skin infections, inflammation, abdominal worms. Only one use is similar in both studies i.e Abdominal worm while in study area mostly people said that they use it for curing skin infections in the form of decoction.

Amaranthus spinosus is used in the form of decoction to cure Gonorrhea, menorrhagia and eczema, snake-bite. Mostly people reported its use as Gonorrhea in Dera Ghazi Khan while in the adjacent area it is used as Diuretic, internal bleeding, diarrhea, excessive menstruation, snake bites, vaginal discharges, nosebleeds, wounds, gonorrhea, eczema and fix the broken bones but they are not using it in the form of decoction. Phoenix dactylifera $L$. is used as Astringent for intestine, sour throat, colds, bronchial catarrh, fever, cystitis, gonorrhea, alcohol intoxication, diarrhea, genito-urinary ailments, diuretic, toothache and sexual disorders in the adjacent areas while in the study area it is used in the form of powder to cure 
bronchitis, fatigue, as expectorant and demulcent., liver diseases, leprosy, anemic pregnant women. Mostly it is used to cure liver diseases as shown in table no 4.

Calotropis procera Aiton. Is reported to be used as asthma, cough, indigestion, joint pain, Regeneration of hairs in the form of decoction which is a concentrated liquid made by boiling. Besides these uses it was used to cure skin diseases [23]. While in the same study done by the ethnobotanist in 2014 it was seen that Eclipta alba L. is used as Hair growth, teeth, memory, sight and hearing, promote sleep, complexion, skin disorders, headache while a new use is reported from the study area which was its use to prevent abortion in females. In this way there are several plants which are mostly used by the people in the area and the detail of all the plants is mentioned in tabl no 4 with detail of uses. While there are some plants which are unique to the study area and not commonly found in adjacent areas like Eleusine flagellifera $L$. that belong to Poaceae family and is used as tonic in Dera Ghazi Khan. As due to lack of modernization and health facilities mostly people are forced to use traditional medicines to cure their common diseases like cold, cough and fever etc. [24].

However this study will provide a comprehensive baseline study about the medicinal plants of the area and their ethno medicinal knowledge from the local people and hakim of the area. [25] Such traditional knowledge is very valuable. In this way the local communities of Dera Ghazi Khan district will get the better chances of employment, native flora will be conserved in a proper way for future utilizations, retain its natural glory and will be used by the industry to produce Nano medicines.

\section{Conclusion}

This study enlist several medicinal plant species which are used by the indigenous people of Dera Ghazi Khan and Result of the study showed that variety of plant species used in making various herbal remedies which plays vital role in the primary healthcare of the local people DG Khan Punjab, Pakistan. Plants having noticeable Fidelity percentage and Use value are precious to these areas. So these plants should be evaluated for further phytochemical screening and biological activities for future drug discovery and development which may lead to plant-based Nano-medicine drug discovery and development.

\section{Declarations}

\section{Ethics approval and consent to participate}

To conduct the ethnobotanical and ethnomedicinal survey of the District Dera Ghazi Khan permission from District authorities were taken. Moreover, before interviewing any participant full information about the study was provided and permission was seek for interview to collection of information

\section{Consent for publication}


Permission for publication was taken from District authorities as well as bioethical committee of University

\section{Availability of data and material}

Voucher specimens are available in herbarium of Lahore College for Women University and full data is part of the manuscript

\section{Competing interests}

It is declared that all authors have no competing interests

\section{Authors' contributions}

TAM conduct the study. HY assist in data collection and manuscript preparation, Zubaida Yousaf help in statistical analysis and manuscript writing and IN she planned and overall supervise the study

\section{Acknowledgements}

We authors are thankful to District authorities for granting permission to conduct study. Moreover, we are also thankful to depute a person as guide to facilitate conduction of study

\section{Funding:}

This study is supported by Higher education Commission Islamabad, Project No.

9845/Punjab/NRP/R\&D/HEC/2017. The Project was funded for collection, analysis, and interpretation of data

\section{References}

1. Diallo D, Hveem B, Mahmoud MA, Berge G, Paulsen BS, Maiga A. An ethnobotanical survey of herbal drugs of Gourma district. Mali Pharm Biol. 1999;37:80-91.

2. Edeoga HO, Okwu DE, Mbaebie BO. Phytochemical constituents of some Nigerian medicinal plants. Afr J Biotechnol. 2005;4:685-8.

3. Gupta MP, Solis PN, Calderon Al, Guionneau-Sinclair F, Correa M, Galdames C, Guerra C, Espinosa A, Alvenda GI, Robles G, Ocampo R. Medical ethno botany of the Teribes of Bocas del Toro. Panama J Ethnopharmacol. 2005;96:389-401.

4. Ali SI, Ome S, Qaisar M. Flora of Pakistan: in Mohammad Afzal and Shehzad A. Mufti Natural History research in Pakistan. PASTIC, 2011. Islamabad.

5. Baquar SR. Medicinal and Poisonous plants of Pakistan, Prints. Pakistan: Karachi; 1989.

6. Zaman MB, Khan AA, Ahmad A. Contribution to the knowledge of medicinal plants. Peshawar: PFl; 1972. 
7. Rojas JJ, Ochoa VJ, Ocampo SA, Muñoz JF. Screening for antimicrobial activity of ten medicinal plants used in Colombian folkloric medicine: A possible alternative in the treatment of nonnosocomial infections. BMC Complement Altern Med. 2006;6:11:86-92.

8. Eisenberg DM, Davis RB, Ettner SL. Trends in alternative medicine use in the United States. 1998; 280: $1569-75$.

9. Hussain MA, Gorsi MS. Antimicrobial Activity of Nerium oleander. Asian J Plant Sci. 2004;3(2):17780.

10. Sheikh SM. 1961. District census report dera ghazi khan part-i general description. Edited by Aslam Abdullah Khan, c.s.p.

11. Tabuti J, Lye K, Dhillion S. Traditional herbal drugs of Bulamogi, Uganda: plants, use and administration. J Ethnopharmacol. 2003;88:19-44.

12. Bennett BC, Prance GT. Introduced plants in the indigenous pharmacopoeia of Northern South America. Econ Bot. 2000;54:90-102.

13. Farnsworth NR. Screening plants for new medicines. In: Wilson EO, Peter FM, editors. Biodiversity. Washington, D. C: National Academy Press; 1988. pp. 83-97.

14. Teklehaymanot T. Ethnobotanical study of knowledge and medicinal plants use by the people in Dek Island in Ethiopia. J Ethnopharmacol. 2009;124:69-78.

15. Friedman J, Yaniv Z, Dafni A, Palewitch D. A preliminary classification of the healing potential of medicinal plants, based on a rational analysis of an ethnopharmacological field survey among Bedouins in the Negev Desert, Israel. J Ethnopharmacol. 1986;16:275-87.

16. Shrestha PM, Dhillion SS. Medicinal plant diversity and use in the highlands of Dolakha district, Nepal. J Ethnopharmacol. 2003;86(1):81-96.

17. Ahmad M, Shazia S, Fazl-i-Hadi S, Hadda TB, Rashid S, Zafar M, Khan MA, Khan MPZ, Yaseen G. An ethnobotanical study of medicinal plants in high mountainous region of Chail valley (District SwatPakistan). J Ethnobiol Ethnomed. 2014;10:1-36.

18. Prashanth D, Asha M, Amit A, Padmaja R. Anthelmintic activity of Butea monosperma. Fitoterapia. 2001;72:421-2.

19. Rajakumar N, Shivanna MB. Ethnomedicinal application of plants in the eastern region of Shimoga District, Karnataka, India. J Ethnopharmacol. 2009;126:64-73.

20. Qureshi R, Bhatti GR, Memon RA. Ethnomedicinal uses of herbs from northern part of Nara desert, Pakistan. Pak J Bot. 2010;42:839-51.

21. Bibi T, Ahmad M, Tareen RB, Tareen NM, Jabeen R, Rehman SU, Sultana S, Zafar M, Yaseen G. Ethnobotany of medicinal plants in district Mastung of Balochistan province, Pakistan. $J$ Ethnopharmacol. 2014;157:79-89.

22. Arshad M, Nisar MF, Majeed A, Ismail S, Ahmad M. Ethnomedicinal flora in district Sialkot, Punjab, Pakistan. Middle-East J Sci Res. 2011;9:209-14. 
23. Muhammad FN, Farrukh J, Muhammad S, Sajil I, Yasmin T, Syed MH, Julia LZ. Ethno-medicinal Uses of Plants from District Bahawalpur, Pakistan. Current Research Journal of Biological Sciences. 2014;6(5):183-90.

24. Azaizeh H, Fulder S, Khalil K, Said O. Ethnomedicinal knowledge of local Arab practitioners in the Middle East Region. Fitoterapia. 2003;74:98-108.

25. Hussain K, Nisar MF, Majeed A, Nawaz K, Bhatti KH. Ethnomedicinal survey for important plants of Jalalpur Jattan, District Gujrat, Punjab, Pakistan. Ethnobotanical Leaflets. 2010;14:807-25.

\section{Figures}

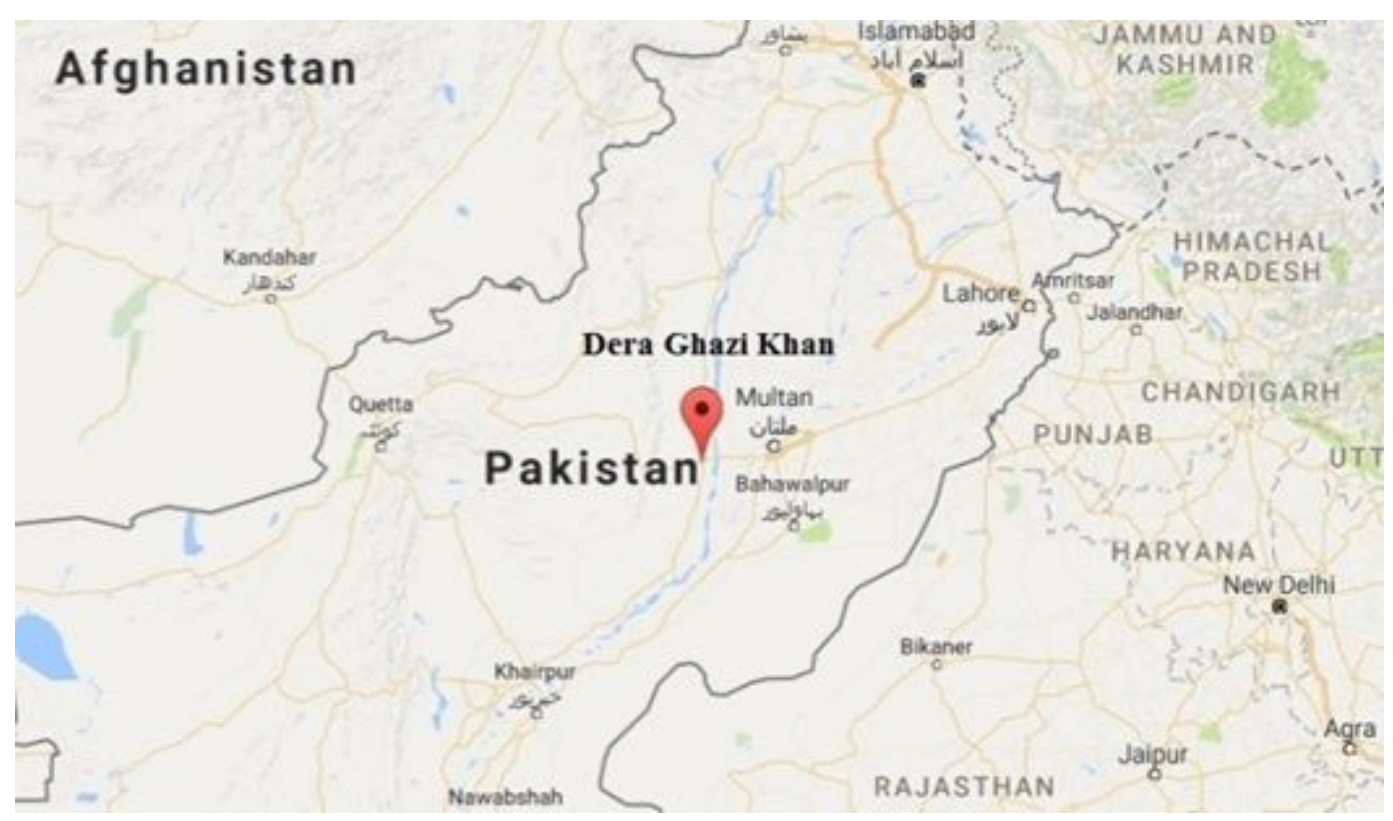

Figure 1

Map of Dera Ghazi Khan

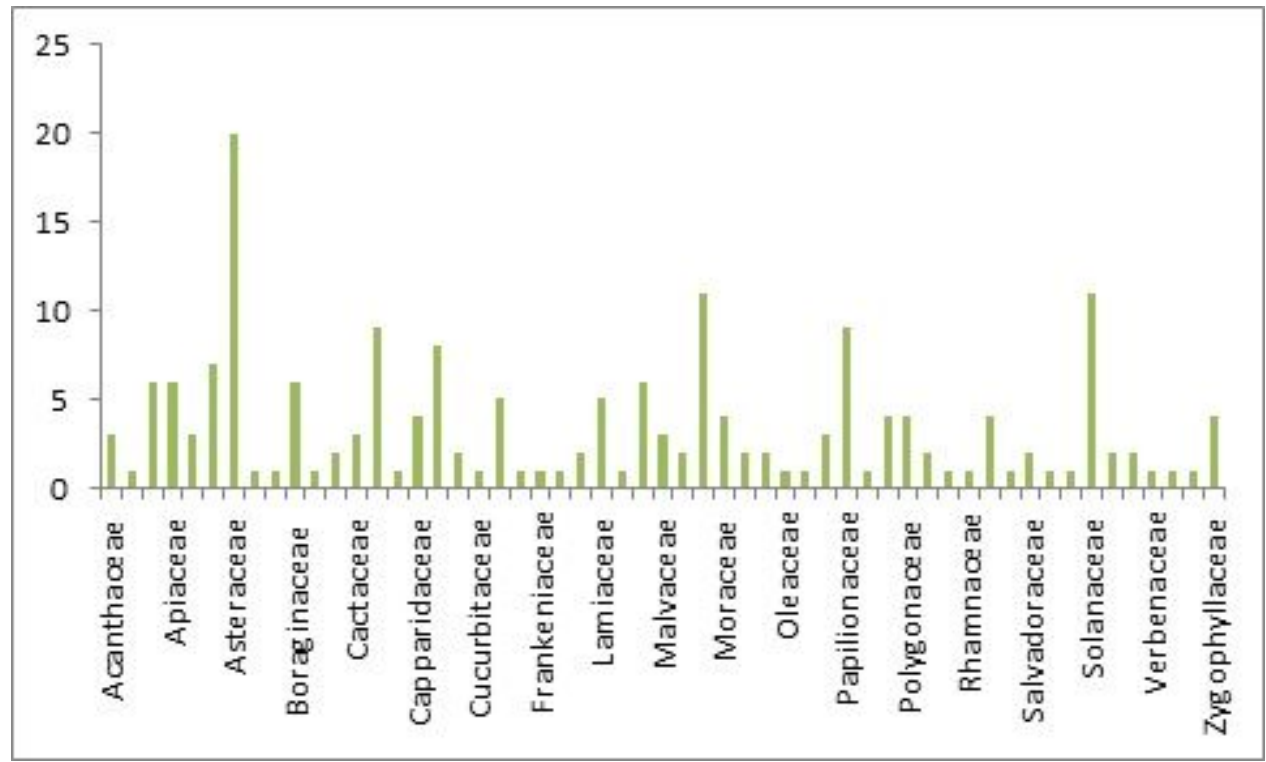


Figure 2

Plant families of medicinal plants

\section{Life Form of Medicinal Plants}

- Herb $\square$ Shrub $\square$ Tree $\square$ Weed

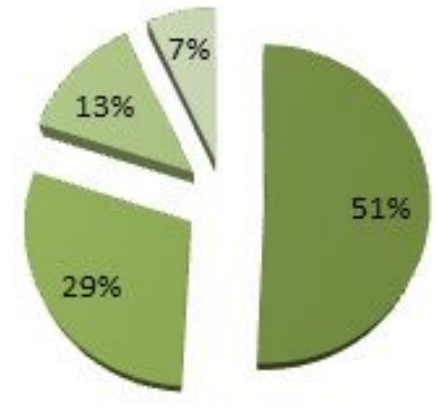

Figure 3

Life form of medicinal plants

\section{Plant part used(\%)}

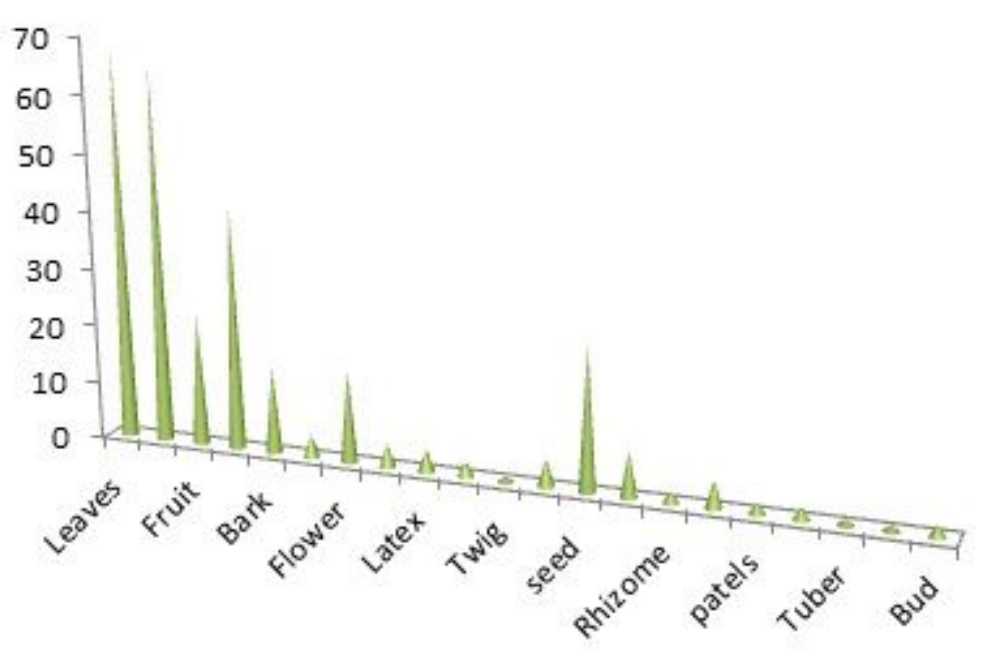

Figure 4

Plant part used 


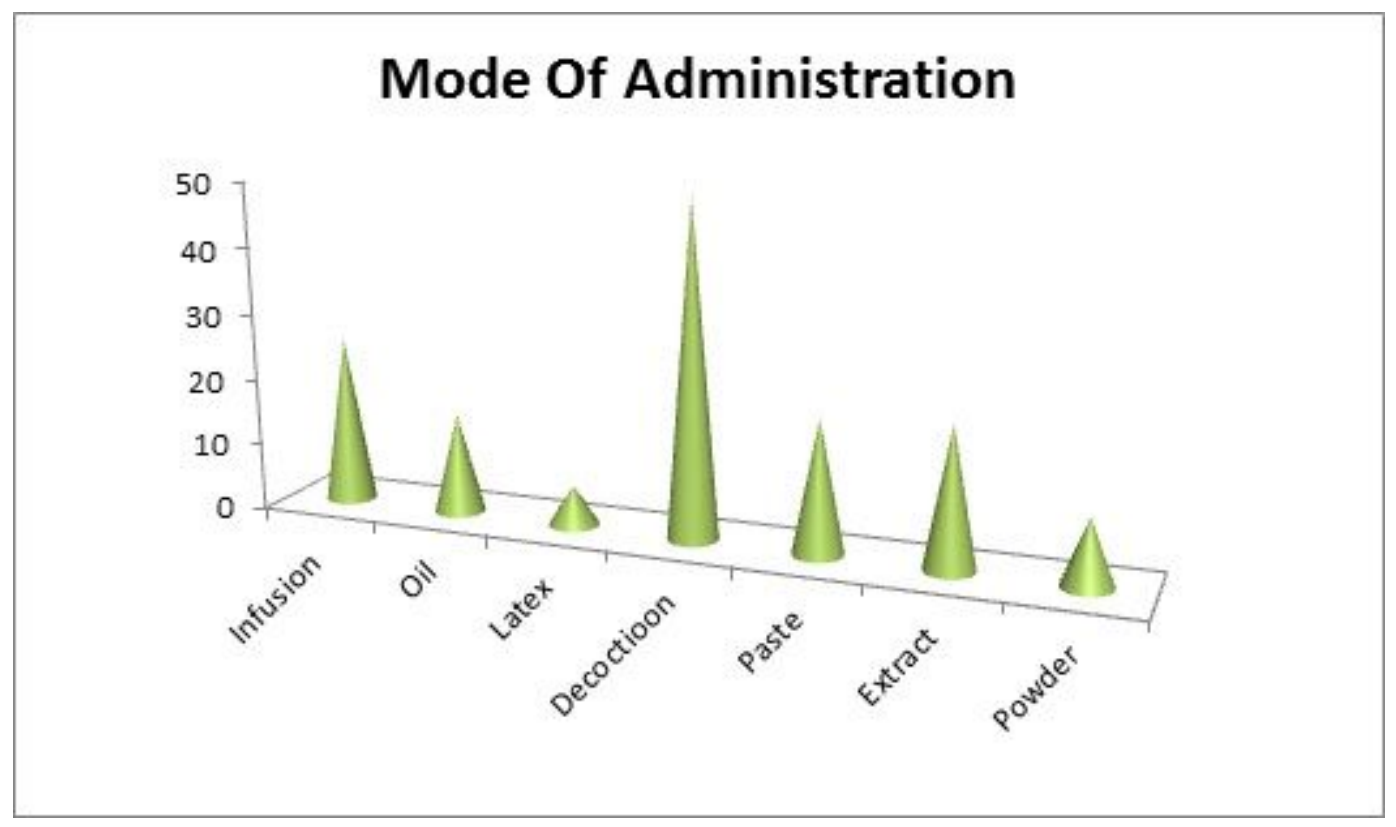

\section{Figure 5}

Mode of Administration

\section{Supplementary Files}

This is a list of supplementary files associated with this preprint. Click to download.

- GraphicalAbstract1.pdf

- GraphicalAbstract1.pdf 